\title{
Morphological, morphometric and histochemical aspects of the labial salivary glands of dogs
}

\section{Aspectos morfológicos, morfométricos e histoquimícos das glândulas salivares labiais de cães}

\author{
Simone Rezende Galvão ${ }^{1}$; Daise Nunes Queiroz da Cunha ${ }^{2 *}$; Ricardo Junqueira \\ Del Carlo; ; Andréa Pacheco Batista Borges 3 ; Laércio dos Anjos Benjamin ${ }^{3}$; \\ Cláudio César Fonseca ${ }^{3}$; Lucas Marcon ${ }^{1}$; Carlos Eduardo Real Pereira ${ }^{1}$
}

\begin{abstract}
The knowledge regarding labial salivary glands is becoming progressively more important, as their application in autologous transplantion, to promote ocular surface lubrication, are an ever-increasing procedure in veterinary medicine. In this study the labial salivary gland was collected, as a single piece, along with the oral mucosa from 10 adult dog cadavers. The sample was removed from the left lower lip marked by the second premolar tooth and extended until the distal edge of the second molar. Morphological, morphometric and histochemical evalutations were performed in the rostral, medial and caudal regions of the sample. The study revealed exocrine, compound, tubuloacinar, mixed and predominantly mucous glands with the presence of serous demilunes associated with a few mucous secreting units, and a duct system formed by intralobular intercalated and striated ducts, interlobular ducts, and a main excretory duct. In the rostral region, there was a lower amount of parenchyma compared to other areas, and the diameter of the acini unvaried in all regions. All three regions of the sample were PAS and Alcian blue positive, demonstrating the presence of neutral, carboxylated, and sulphated mucins. Serous demilunes reacted positively to Xylidine Ponceau staining indicating the presence of proteins.
\end{abstract}

Key words: Glandular characterization. Labial salivary glands. Minor salivary glands. Canine.

\section{Resumo}

O conhecimento das características das glândulas salivares labiais vem se tornando importante à medida que aquelas vêm sendo empregadas, na medicina veterinária, como transplante autógeno para promover lubrificação da superfície ocular. As glândulas salivares labiais, juntamente com a mucosa oral, foram removidas de 10 cadáveres de cães adultos, como peça única, no lábio inferior esquerdo, da região anatômica do segundo dente pré-molar até a borda distal do segundo molar e amostras das regiões rostral, média e caudal da peça foram processadas para avaliações morfológicas, morfométricas e histoquímicas. O estudo revelou glândulas exócrinas, compostas, túbuloacinosas, mistas, predominantemente mucosas, com presença de semiluas serosas associadas a algumas unidades secretoras mucosas, sendo seu sistema de ductos formado por ductos intralobulares intercalares, ductos intralobulares estriados, ductos

\footnotetext{
${ }^{1}$ Discentes do Curso de Doutorado do Programa de Pós-Graduação em Medicina Veterinária, Departamento de Veterinária, Universidade Federal de Viçosa, UFV, Viçosa, MG, Brasil. E-mail: srgalvao@ufv.br; lucasmarcon@yahoo.com.br; carlos. pereira@ufv.br

2 Pós-Doutora, Médica Veterinária, Pesquisa Clínica Veterinária, Zoetis, Mogi Mirim, SP, Brasil. E-mail: daisenunes@gmail.com

3 Profs., Departamento de Veterinária, UFV, Viçosa, MG, Brasil. E-mail: ricarlo@ufv.br; andrea@ufv.br; laercio@ufv.br; fonseca@ ufv.br

* Author for correspondence
} 
interlobulares e ducto excretor principal. Na região rostral havia menor quantidade de parênquima em relação às demais regiões, e o diâmetro dos ácinos se manteve equivalente nas três regiões. Houve reação positiva ao PAS e ao Alcian blue nas três regiões, demonstrando presença de mucinas neutras, ácidas carboxiladas e ácidas sulfatadas. As semiluas serosas apresentaram reação positiva ao Xylidine Ponceau, indicando presença de proteínas.

Palavras-chave: Caracterização glandular. Glândulas salivares labiais. Glândulas salivares menores.

\section{Introduction}

The salivary glands of dogs are classified as major and minor. The later are systematized as parotid, mandibular, sublingual and zygomatic (BANKS, 1991a; DYCE et al., 2004). According to Banks (1991a), its secretory via are formed by intercalated intralobular, striated intralobular, lobular, intralobular, lobar, and excretory ducts. The minor salivary glands are constituted of miniaturized forms of the major glands and may be mucous, serous or mixed mistas (BANKS, 1991a; FRAPPIER, 2006). They are located in the interior of the lamina propria-submucosa in close proximity with the epithelial lining and are formed by the labial, lingual, buccal and palatine glands (BANKS, 1991a; DYCE et al., 2004; FRAPPIER, 2006).

Salivary glands share similar organizational patterns, although in the minor glands these patterns are not so elaborated (BANKS, 1991a), and in which the shape of the secretory unit may be acinar, tubular or tubuloacinar (FRAPPIER, 2006) and the duct system are less developed (HAND et al., 1999) and devoid of striated ducts (FRAPPIER, 2006).

Labial salivary glands have been described as an alternative lubricant source for the ocular surface in humans (MURUBE, 1997), and most recently in veterinary medicine (ANGÉLICO et al., 2011; ROCHA, 2012). Although the type of secretion from labial glands is well stablished in humans (RAUS, 2003; SOARES; FRANÇA, 2005), there still are contradictions associated with the type of secretion in dogs., for example, these may be classified as mucous by Banks (1991a), or mixed, predominantly mucous by Rocha (2012).

The present study aimed to describe the morphological, morphometric and histochemical aspects of the labial salivary glands of dogs.

\section{Materials and Methods}

All procedures were approved by the Ethics Committee on Animal Experimentation (protocol number 57/2010) of Universidade Federal de Viçosa. The principles observed in this study are specified in the European Convention for the Protection of Vertebrate Animals and in the National Research Council Guide for the Care and Use of Laboratory Animals. A consent authorizing the postmortem procedures in each dog was signed by each owner.

\section{Animals}

Ten adult male mongrel dogs weighing between 14 and $21 \mathrm{~kg}$ that died from unknown causes were used during this study to investigate the function of the salivary glands.

\section{Glandular obtention and histological techniques}

Immediately after death, the labial salivary glands were identified in the lower lips of the left antimere. Their exact location extended from the lower second premolar tooth to the distal edge of the second molar. Subsequently, they were dissected and removed as a single piece along with the oral mucosa. Next, the sample was fragmented perpendicularly to its greater axis. This technique allowed the acquisition of several glands distributed through three regions (rostral, medial and caudal).

Samples were fixed in formaldehyde $4 \%$ for 24 hours, in ambient temperature, and processed using conventional histological techniques for paraffin inclusion. Sections of $5 \mu \mathrm{m}$ thick were manually cut with microtome (Spencer), transferred to glass slide, and stained with Haematoxylin-Eosin for morphological and morphometric evaluations. 
For histochemical characterization the following methods were used: Periodic Acid-Schiff (detection of neutral glycoconjugates), Alcian blue $\mathrm{pH} 2.5$ (detection of acidic glycoconjugates with both sulphur groups and carboxyl groups), Alcian blue pH 0.5 (detection of sulfated glycoconjugates), and Xylidine Ponceau (detection of proteins).

Slides were visualized using light microscope (Olympus BX50) connected to a camera (CMOS). Images were obtained and analyzed using software (TSView).

\section{Morphological, morphometrical and histochemical analysis}

The morphological characteristics of the glands were determined based on shape, secretory unit type, and duct system. For morphometric evaluations, 10 distinct fields were randomly chosen per animal, in each of the rostral, medial, and caudal regions, to quantify the structure of the parenchyma and of the stroma. Measurements were made using images obtained with 10x objective lens. Quantification was perfomed by counting the points of intersection on the gland components using a counting grid of $90.000 \mu \mathrm{m}^{2}$ in area with 441 intersection points.

The gland acini diameters were measured using 30 typical acini images (10x objective lens) per animal, in each of the regions: rostral, medial, and caudal. The morphometric indices were determined using an image analyzer software (Image-Pro Plus 1.3.2, 1994).

The characterization of the histochemical patterns of the glands was based on the organic components of the secretion by the secretory units (acini and tubules), being classified as positive or negative. A positive reaction was confirmed by the magenta color for PAS, blue for Alcian blue and reddish-orange for Xylidine Ponceau.

\section{Statistical analysis}

Variables were tested for normality (Lilliefors) and for homocedasticity (Cochran), but were not normally distributed. Therefore, the data were submitted to the non-parametrical test of KruskalWallis. The software Statistica 7.0 was used and a significance level of 5\% was admitted.

\section{Results}

\section{Morphology}

The labial salivary glands collected from the inferior left antimere were readily palpable and clustered towards the caudal region. The glands, in the three evaluated regions, were deep in the lining mucosa of the vestibular cavity at the tunica submucosa, and involving them was this connective tissue extending across the parenchyma, and dividing the gland into structures like lobules (Figure 1A).

The glands were described as exocrine, compound, tubuloacinar, mixed predominantly mucous, with cells that constituted structures like demilunes associated with some serous mucous secretory units. There were observed many structures that secreted only mucous and some others seromucous. The mucous secreting cells presented a flat nucleus, localized in the basal surface and granular cytoplasm, while serous cells were demilune and had round nucleus (Figure 1B).

There were observed intralobular ducts lined by simple epithelium, continuous with the secretory units denominated intercalated ducts (Figure 1C); intralobular ducts of simple epithelium with cells presenting basal striation, designated striated ducts (Figures 1D, 1E); interlobular ducts localized in the septum of conjunctive tissue, presenting bilayered epithelium (Figure $1 \mathrm{~F}$ ); and the main excretory duct with bylayered epithelium. 
Figure 1. Photomicrographs of the rostral portion of labial salivary glands in dogs. A: Connective tissue surrounding the gland (arrow) extending into the parenchyma (arrowhead), dividing it into like-lobules-structures (L). B: Cells constituting structures like serous demilunes associated to some mucous secretory units (arrowhead). C: Intercalar duct (DIC). D: striated duct (DE) characterized by striations $(*)$ in transition into intercalary duct. E: striated duct (DE) characterized by striations $\left(^{*}\right)$ in transition into interlobular duct. F: Interlobular duct (DIL). HE. Bars: A: 500 $\mu \mathrm{m}$; B-F: $50 \mu \mathrm{m}$.

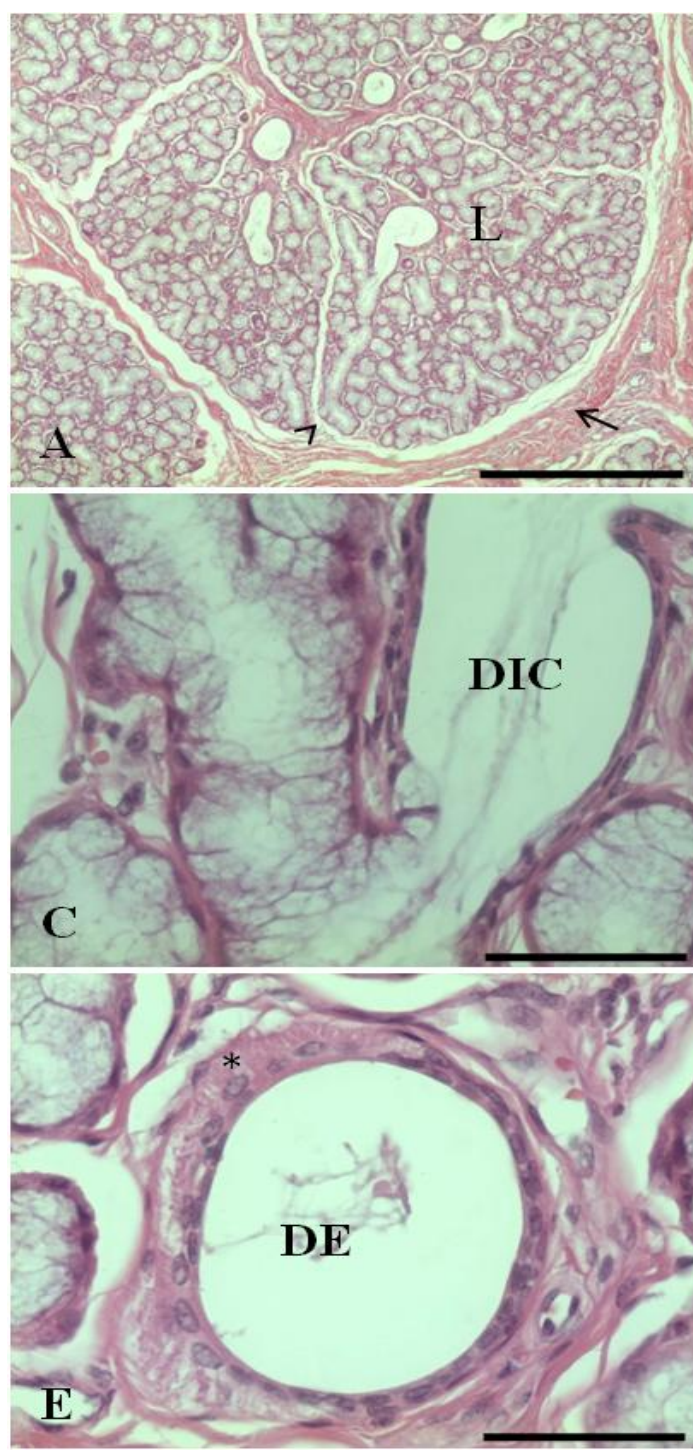

\section{Morphometry}

In the morphometric analysis of the three regions of the salivary gland (rostral, medial, and caudal), the quantification values for the parenchyma and

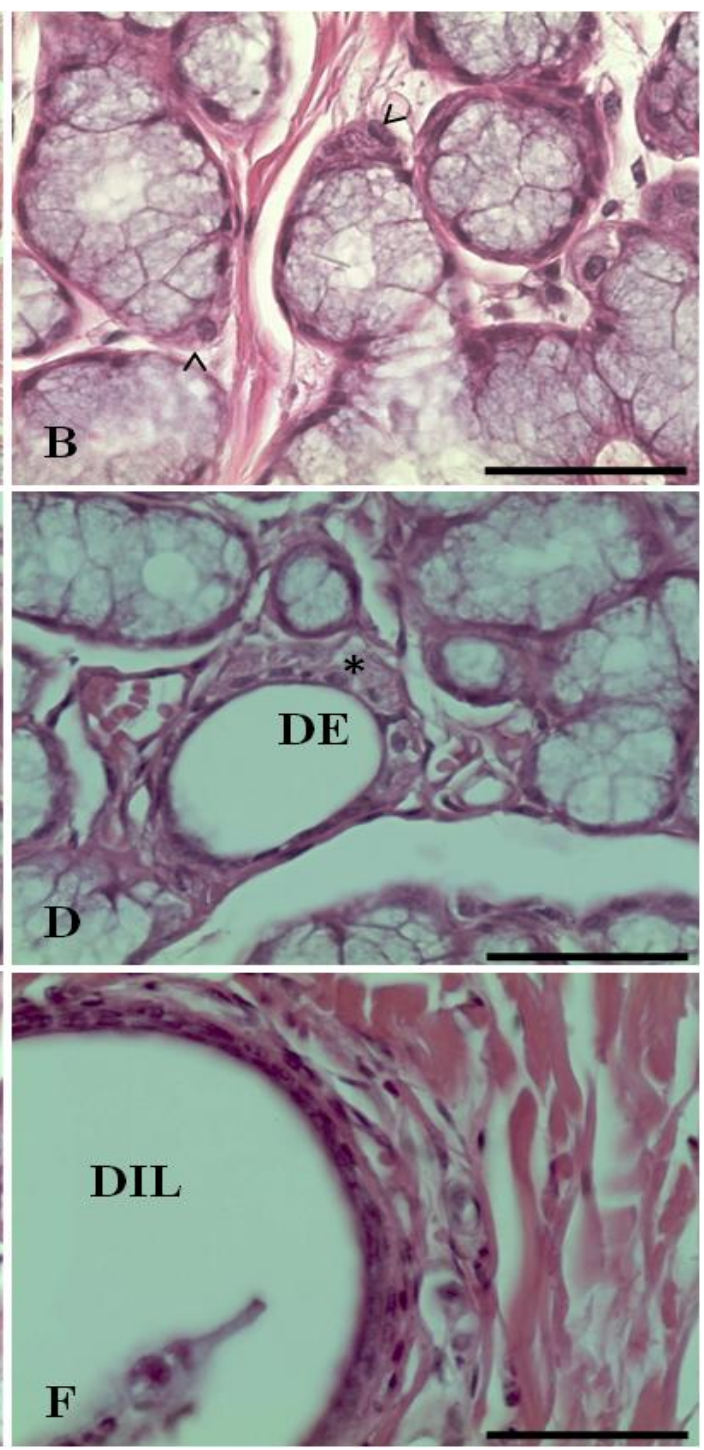

stroma of the rostral portion differed $(\mathrm{p}<0,05)$ from the others (Table 1). However, no difference $(\mathrm{p}>0,05)$ was found among the three regions as to the diameter of the acini (Table 1). 
Table 1. Mean values for quantitation of parenchyma, stroma, and acini diameter from rostral, medial, and caudal regions of the labial salivary glands in dogs.

\begin{tabular}{lrcc}
\hline \multirow{2}{*}{ Location } & \multicolumn{3}{c}{ Regions } \\
\cline { 2 - 4 } & Rostral & Medial & Caudal \\
\hline Parenchyma & $328,31 \pm 57,05^{\mathrm{a}}$ & $348,27 \pm 53,27^{\mathrm{b}}$ & $356,56 \pm 45,40^{\mathrm{b}}$ \\
Stroma & $112,69 \pm 57,05^{\mathrm{a}}$ & $92,73 \pm 53,27^{\mathrm{b}}$ & $84,44 \pm 45,40^{\mathrm{b}}$ \\
Acini & $206,52 \pm 25,67^{\mathrm{a}}$ & $211,58 \pm 32,90^{\mathrm{a}}$ & $206,35 \pm 29,95^{\mathrm{a}}$ \\
\hline
\end{tabular}

Values are expressed as mean \pm standard deviation.

Values with different superscripted small letters in the same row indicate statistical difference $(\mathrm{p}<0.05)$ by the non-parametric test of Kruskal-Wallis.

\section{Histochemistry}

The histochemical evaluation from the three regions demonstrated that the mucous acini and tubules composing the secretory unit were positive to the PAS (Figure 2A) and Alcian blue methods with different intensity of the reaction between
pH 2.5 (Figure 2B) and pH 0.5 (Figure 2C). On the other hand, the Xylidine Ponceau was negative (Figure 2D).

The cells that constituted demilunes like structures presented a negative reaction to the Alcian blue $\mathrm{pH}$ 2,5 (Figure 2E) and were positive to Xylidine Ponceau (Figure 2F).

Figure 2. Photomicrographs of the medial portion of labial salivary glands in dogs. A: acini and tubules, PAS positive reaction. B: acini and tubules, positive reaction to Alcian blue in $\mathrm{pH}$ 2.5. C: acini and tubules, positive reaction to Alcian blue in $\mathrm{pH}$ 0.5. D: acini and tubules, negative reaction to Xylidine Ponceau. E: serous demilunes (arrow), negative reaction to Alcian blue in $\mathrm{pH}$ 2.5. F: serous demilunes (arrow), positive reaction to Xylidine Ponceau. Bars: A-D: $200 \mu \mathrm{m}$; E-F: $50 \mu \mathrm{m}$.
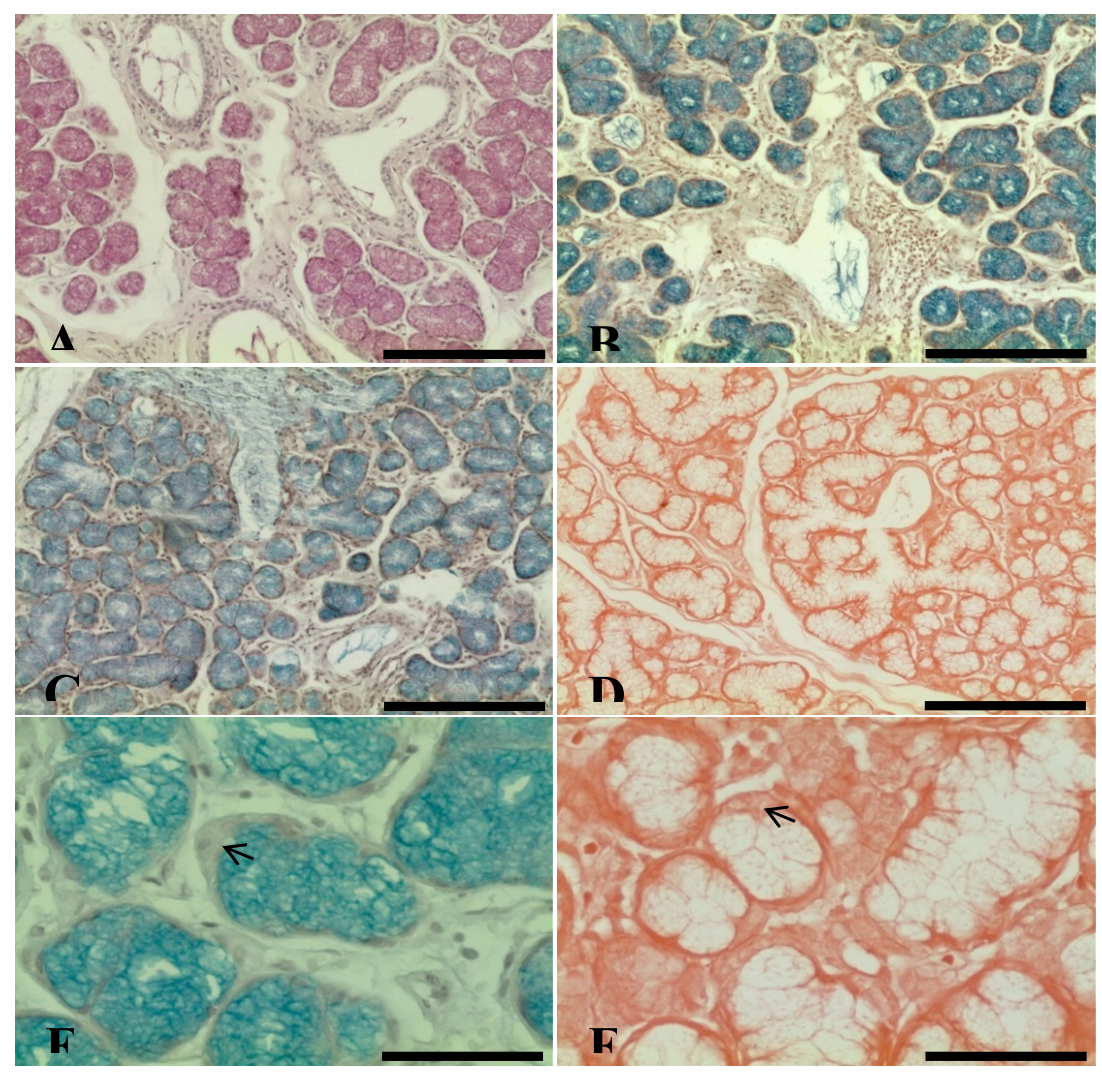


\section{Discussion}

The salivary glands were grouped and easily palpable in the inferior lip, exactly, between the anatomical region of the second premolar tooth and the second inferior molar. Therefore, this location is recommended to be the primary site for gland donation for transplantation purposes, as suggested by Angélico et al. (2011) and Rocha (2012).

A capsule of connective tissue surrounding the labial glands was observed in all three regions. Similar structure was observed by Daniels (1984) in salivary glands of humans and by Rocha (2012) in dogs, although Bacha and Bacha (2003) did not report such findings. The labial glands presented a lobular aspect due to connective tissue that surrounds and intermingles the glands, diving it into portions as described by Hand et al. (1999).

The morphological and histochemical analysis allowed for the classification of the glands as exocrine, compound, tubuloacinar, mixed and predominantly mucous agreeing with the classification of Rocha (2012). However, Banks (1991a) described these glands as mucous, which should not, because in our study other cells beyond mucous cells were observed and these were constituted of structures like demilunes, with round nucleus, associated to few mucous secretory units which are classified as serous cells (BANKS, 1991b; HAND et al., 1999).

It should be noted that when a method to testify the presence of glycoconjugates (mucin) was applied these same structures presented different patterns of histochemical reactions (COOK, 1996).

In regards to the secretory pathway, Frappier (2006) alleged that the striated ducts are not characteristically of minor salivary glands of animals. However, in addition to intercalated ducts were observed within the lobes of the labial glands, ducts with simple epithelium with striations in the basal portion of the cell, which according to Banks (1991a), are named striated ducts, based on the presence of striations resulting from the perpendicular orientation of the mitochondria within compartments formed by the basal membrane. The presence of striated ducts further enhances the classification of these glands as predominantly mucous with presence of serous demilunes because, according to Banks (1991a), these ducts are not exclusively present in mucous salivary glands.

The difference in morphometric quantification of the parenchyma and stroma of the rostral region compared to other regions observed in the morphometric analysis, was evidenced by the lower amount of parenchyma in this region. In regards to measuring the diameter of the lobes, there was no difference between the three regions maintaining the morphology of the glands, regardless of region, showing the pattern of glandular structure.

Histochemical assessment of minor salivary glands revealed that they were PAS positive and therefore secrete neutral glycoconjugates. They also exhibited alcianophilia, i.e., were Alcian blue positive at $\mathrm{pH} 2.5$ demonstrating that they secreted acid glycoconjugates, and at $\mathrm{pH} 0.5$, secrete acid sulfated glycoconjugates, similar to the classification established by Cook (1996) and Munyala et al. (2009).

The difference in reaction intensity observed with Alcian blue at $\mathrm{pH} 2.5$ compared to $\mathrm{pH} 0.5$, in the three regions, and in all animals from this study, demonstrate the presence of glycoconjugates carboxylated acids.

The glycoconjugates, or salivary mucins secreted by mucous cells, as shown by histochemical analysis act as a lubricant, maintaining mucosal integrity (MUNYALA et al., 2009). For Samar et al. (1995), the salivary mucins have properties such as low solubility, high viscosity and stickiness, which makes them able to concentrate on the surface of the mucosa and provide an effective barrier against drying.

Different glycoconjugates were found in the minor salivary glands, as observed by Cook (1996), in other words, they may be present as a single type within the tissue or, more commonly, as a mixture of 
different types. Moreover, the reaction pattern was constant in the three areas evaluated in all animals.

The positive reaction to Xylidine Ponceau, demonstrated by the cells that constituted structures like demilunes, denote the presence of proteins that, combined with alcioanophilia and PAS positive in the mucosal secretory units, confirm the existence of seromucus secretory units in labial salivary glands of dogs. Almansour and Bashir (2007), similarly confirmed the glandular type by immunohistochemical criteria.

\section{Conclusions}

This study shows that the labial salivary glands: 1. are exocrine compound, tubuloacinar, mixed, predominantly mucous, with the presence of serous demilunes containing some mucous secretory units; 2. the duct system consists of intralobular intercalated and striated ducts, interlobular ducts, and by the main excretory duct; 3 . present a lower amount of parenchyma in the rostral region and the acini diameter unvaried in the three anatomical regions; and 4. secrete protein in addition to neutral, acidic carboxylated and sulphated acidic mucins.

\section{Acknowledgments}

DEL CARLO R.J. and BORGES A.P.B. was funded by CNPq (National Council for Scientific and Technological Development - Brazil).

\section{References}

ALMANSOUR, M. I.; BASHIR, M. J. Morphological, histological and histochemical study of the lingual salivary glands of the little egret. Saudi Journal of Biological Sciences, Riyadh, v. 1, n. 1, p. 75-81, 2007.

ANGÉLICO, G. T.; RANZANI, J. J. T.; BRANDÃO, C. V. S.; SCHELLINI, A. S.; PADOVANI, C. R. Transplante de glândulas salivares menores no tratamento da ceratoconjuntivite seca em cães. Arquivo Brasileiro de Medicina Veterinária e Zootecnia, Belo Horizonte, v. 63, n. 5, p. 1087-1092, 2011.
BACHA, W. J.; BACHA, L. M. Sistema digestório. In: Atlas colorido de histologia veterinária. 2. ed. São Paulo: Roca, 2003. cap. 13, p. 195-273.

BANKS, W. J. Epitélios. In: _. Histologia veterinária aplicada. 2. ed. São Paulo: Manole, 1991b. cap. 5, p. 6086.

. Sistema digestivo II - órgãos extramurais. In: . Histologia veterinária aplicada. 2. ed. São Paulo: Manole, 1991a. cap.22, p. 465-480.

COOK, H. C. Carbohydrates. In: BANCROFT, J. D.; STEVENS, A. (Ed.). Theory and practice of histological techniques. $4^{\text {th }}$ ed. New York: Churchill Livingstone, 1996. p. 173-212.

DANIELS, T. E. Labial salivary gland biopsy in Sjögren's Syndrome. Arthritis \& Rheumatism, Atlanta, v. 27, n. 2, p. 147-156, 1984.

DYCE, K. M.; SACK, W. O.; WENSING, C. J. G. Aparelho digestório. In: Tratado de anatomia veterinária. 3. ed. Rio de Janeiro: Elsevier, 2004. cap. 3, p. 99-145.

FRAPPIER, B. L. Digestive system. In: EURELL, J. A.; FRAPPIER, B. L. (Ed.). Dellmann's textbook of veterinary histology. $6^{\text {th }}$ ed. Iowa: Blackwell, 2006. $\mathrm{p}$. 170-211.

HAND, A. R.; PATHMANATHAN, D.; FIELD, R. B. Morphological features of the minor salivary glands. Archives of Oral Biology, Philadelphia, v. 44, p. S3-S10, 1999. Supplement 1.

MUNYALA, R.; LIUMSIRICHAROEN, M.; PONGKET, P.; PRAPONG, T.; SUPRASERT, A. Glycoconjugates in the secretory epithelium of the mandibular salivary gland of Malayan Pangolin (Manis javanica). KKU Veterinary Journal, Khon Kaen, v. 19, n. 2, p. 162-169, 2009.

MURUBE, J. Cirugía substitutiva del ojo seco y transplantes glandulares. In: _ Ojo seco. Quito: Tecnimedia, 1997. cap. 40, p. $\overline{207-221}$.

RAUS, P. Radiosurgery aids in salivary gland transplants for severe dry eye. Ocular Surgery News, New York, v. 1, n. 12, p. 16-18, 2003.

ROCHA, G. L. S. Transplante autólogo das glândulas salivares labiais, oclusão cirúrgica dos pontos lacrimais ou associação das duas técnicas no tratamento da ceratoconjuntivite seca em cães. 2012. Tese (Doutorado em Cirurgia e Oftalmologia) - Universidade Federal de Minas Gerais, Belo Horizonte. 
SAMAR, M. E.; AVILA, R. E.; FABRO, S. P. de; CENTURION, C. Structural and cytochemical study of salivary glands in the Magellanic Penguin Spheniscus magellanicus and the Kelp Gull Larus dominicanus. Marine Ornithology, Burnaby, v. 23, n. 2, p. 153-156, 1995.
SOARES, E. J. C.; FRANÇA, V. P. Transplante de glândulas salivares labiais no tratamento do olho seco grave. Arquivos Brasileiros de Oftalmologia, São Paulo, v. 68, n. 4, p. 81-489, 2005. 